\title{
AMELIORATIVE EFFECTS OF VANILLIN AGAINST METRIBUZIN-INDUCED OXIDATIVE STRESS AND TOXICITY IN RATS
}

\author{
LILIA KADECHE ${ }^{1}$, EZZEDDINE BOUROGAA ${ }^{2}$, MONGI SAOUDI ${ }^{2}$, AMEL BOUMENDJEL ${ }^{1}$, ASSIA DJEFFAL ${ }^{1}$, \\ ABDELFATTAH EL FEKI ${ }^{2}$, MAHFOUD MESSARAH ${ }^{1}$
}

\author{
${ }^{1}$ Laboratory of Biochemistry and Environmental Toxicology, Faculty of Sciences, University of Badji Mokhtar, BP 12 Sidi Amar, Annaba \\ Algeria, ${ }^{2}$ Laboratory of Animal Ecophysiology, Faculty of Sciences, Sfax, Soukra road-Km 3.5, BP 802, 3018 Sfax, Tunisia \\ Email: mahfoud.messarah@univ-annaba.dz
}

Received: 30 Jul 2016 Revised and Accepted: 05 Nov 2016

\begin{abstract}
Objective: Vanillin (Va), a phenolic substance is a natural antioxidant with proven free radical scavenging activity and offers protection against oxidative damage. This study was designed to investigate the ameliorative effect of Va against metribuzin (Mtz) pesticide-induced toxicity and oxidative stress in rats.
\end{abstract}

Methods: Thirty-two rats were equally divided into four groups: control, vanillin (Va), metribuzin (Mtz) and metribuzin plus vanillin (Mtz+Va). Metribuzin (133.33 mg/kg, 1/20 LD ${ }_{50}$ ) was given to rats through their drinking water. Vanillin was supplemented (150 mg/kg) intraperitoneally for three weeks. At the end of experiments, various haematological and biochemical parameters were estimated. Antioxidant defence systems as GPx enzyme activities, GSH and MDA contents were determined in tissues as the indicators of oxidative stress.

Results: Compared with the control, a significant decrease in the levels of red blood cells ( $\mathrm{p} \leq 0.05)$, haemoglobin $(\mathrm{p} \leq 0.003)$ and hematocrit $(\mathrm{p} \leq 0.02)$ were noticed in the metribuzin-exposed group. The biochemical evaluation showed significantly higher values (『 0.0001) for glucose, urea, creatinine and bilirubin. Also, Mtz treatment caused significant perturbations in lipids profile as plasma levels of total cholesterol ( $\mathrm{p} \leq 0.0001)$ and triglycerides ( $\mathrm{p} \leq 0.004)$. MDA levels increased in all the tissues of rats exposed to Mtz whereas the fluctuation in GPX enzyme activities and GSH levels were observed compared with controls. However, treatment with vanillin significantly normalised haematological profiles, serum biochemical profile and modulated all the oxidative stress parameters.

Conclusion: The use of vanillin appeared to be beneficial to rats, to a great extent in attenuating and restoring the damage sustained by metribuzin exposure.

Keywords: Metribuzin, Vanillin, Antioxidants, Oxidative stress, Pesticides

(C) 2017 The Authors. Published by Innovare Academic Sciences Pvt Ltd. This is an open access article under the CC BY license (http://creativecommons.org/licenses/by/4. 0/J DOI: http://dx.doi.org/10.22159/ijpps.2017v9i1.14258

\section{INTRODUCTION}

Pesticides comprise a heterogeneous group of chemicals which are considered as one of the main factors involved in environmental contamination of today's world. These toxic chemicals designed to act as poison to the pests are able to produce devastating effects on intoxicating non-target organisms, including humans [1]. In fact, pesticides represent a major concern for human health and contribute significantly to many disease states including cancer, neurodegeneration and other chronic health effects [2]. Metribuzin (Mtz) a pesticide often used on vegetable crops to control broadleaf and grassy weed species [3] has also shown significant toxicity to humans [4] and animals [5, 3]. It has been reported that metribuzin is most likely to affect liver [3, 6], kidney [7], lipids profiles and blood chemistry [6]. Also, Velisek et al. [7] demonstrated that metribuzin has potentially induced hepatotoxicity in vivo.

Thus, it has been previously suggested that several pesticides exert their biological effects mainly through electrophilic attack of cellular constituents with simultaneous generation of reactive oxygen species (ROS) [8] which is a major cellular source of oxidative stress [9] and ultimately results in widespread oxidation of biomolecules includes lipids, proteins and nucleic acid [10]. The cytotoxic action of Mtz is also associated with the generation of ROS causing oxidative damage $[3,6]$.

To control the level of reactive oxygen species (ROS) and to protect cells under stress conditions, mammalian tissues contain several enzymatic (catalase CAT, superoxide dismutase SOD and glutathione peroxidase GPx) and non-enzymatic antioxidants (glutathione GSH), that scavenge ROS $[11,12]$. Due to continuous exposure of pesticides, the level of these endogenous antioxidants decreases leading to accelerated cell death [11]. However, any compound, natural or synthetic with antioxidant properties might contribute towards the partial or total alleviation of this type of damage [13, 14]. Antioxidants, both from natural and synthetic sources have proved to be highly effective to control the magnitude of free radicals production, to prevent its undesirable effects, as well as to support the organism antioxidant and detoxifying mechanisms [15].

Indeed, many plant extracts have been reported to have multiple biological effects including antioxidant properties [16]. Vanillin (4hydroxy-3-methylbenzaldehyde) is a good example, which is a primary component of the vanilla bean extract [17]. It is one of the most widely used flavour components in beverage, food preservatives, cosmetics and drugs industry with an estimated annual worldwide consumption of more than 2000 tons [18] but the compound is mainly synthetically produced because the naturally derived product is expensive [17]<smiles>COc1cc(C=O)ccc1O</smiles>

Fig. 1: Structure of vanillin

Besides its industrial and food application, this compound has been the subject of several scientific investigations in the last years, such as the identification of antioxidant properties, antimicrobial activity, as well as antimutagenic and anticarcinogenic actions. Part of these biological properties can be attributed to the fact that vanillin (fig. 1) is a phenolic compound [19]. 
To the best of our knowledge, no previous study of the efficacy of vanillin on pesticide toxicity has been reported. Therefore, the current study was designed to evaluate the protective effects of a synthetic antioxidant vanillin (Va) against oxidative damage in rats subacutely exposed to metribuzin (Mtz) pesticide.

\section{MATERIALS AND METHODS}

\section{Drugs and chemicals}

The commercial herbicide metribuzin $\left(\mathrm{C}_{8} \mathrm{H}_{14} \mathrm{~N}_{4} \mathrm{OS}\right.$; CAS. Nos metribuzin 21087-64-9) used in this study was obtained from (INRAA, Algeria). It was tested in the form of Sencor WP 70 pesticide, of which the active substance was metribuzin in the amount of $70 \%$. All other reagents used were of high quality and analytical grade. Vanillin [IUPAC name 4-hydroxy-3-methoxybenzaldehyde, chemical formula $\left(\mathrm{CH}_{3} \mathrm{O}\right)(\mathrm{OH}) \mathrm{C}_{6} \mathrm{H}_{3} \mathrm{CHO}$, the molecular weight of 152.15] was obtained from Hi-Media laboratories.<smiles>CSC1=NNC(C(C)(C)C)C(=O)N1N</smiles>

Fig. 2: Structural formula of metribuzin

\section{Animals}

A total of 32 male Wistar rats weighing approximately $200-250 \mathrm{~g}$ were used for this experiment. They were procured from the Pasteur Institute (Algiers, Algeria). Rats were maintained under standard conditions of temperature $\left(22 \pm 2{ }^{\circ} \mathrm{C}\right)$, humidity $(40 \%)$ and photoperiod. Food (standard diet, supplied by the ONAB, Algiers, Algeria) and water were available ad-libitum. After two weeks of acclimatisation, rats were divided among the control and test groups. All experiments were carried out in accordance with ethical approval.

\section{Experimental design}

Animals were randomly divided into 4 groups (8 rats in each):

Group I: Control group (C) rats received drinking water.

Group II (Va): Animals received vanillin dissolved in $0.9 \%$ saline solution and administered by intraperitoneal injection at a dose of $150 \mathrm{mg} / \mathrm{kg}$ body weight (in a volume of $1 \mathrm{ml} / \mathrm{kg}$ body weight).

Group III (Mtz): Rats given orally metribuzin at a dose of 133.33 $\mathrm{mg} / \mathrm{kg}$ body weight $\left(1 / 20 \mathrm{LD}_{50}\right)$ in drinking water.

Group IV (Mtz+Va): Rats treated daily with both metribuzin and vanillin as in group two and three.

Rats in the group (C) and (Mtz) were daily given physiological saline $(0.9 \% \mathrm{NaCl}, 1 \mathrm{ml} / \mathrm{kg}$ body weight) by intraperitoneal injection (i. p.) during the whole course of the experiment.

Vanillin and metribuzin doses were based in previous studies [14] and [20] respectively. The treatment was continued for a period of three consecutive weeks, and all individuals were weighed one every week. At the end of the experiment, total body weights were recorded, and animals were sacrificed by decapitation without anaesthesia to avoid animals stress. Different organs namely liver, kidney, brain and testis were removed and weighed in order to obtain the relative weight of each organ (\%) which was calculated as $\mathrm{g} / 100 \mathrm{~g}$ body weight.

\section{Blood collection and haematological profile}

At the time of sacrifice, blood samples for biochemical assays were collected in tubes without anticoagulant and serum was obtained by centrifugation of the samples for $15 \mathrm{~min}$ at $\left(3000 \mathrm{rpm}, 4^{\circ} \mathrm{C}\right)$. Blood samples for haematological analysis were collected in tubes containing EDTA.

The haematological analysis was performed using an automatic haematological analyser (Auto Hematology Analyz, MODEL PCE-210N,
Japan). Haematological parameters evaluated were total red blood cell (RBC), haemoglobin (Hb) concentration, hematocrit (HCT), mean corpuscular haemoglobin $(\mathrm{MCH})$, mean corpuscular volume (MCV) and meant corpuscular haemoglobin concentration (MCHC).

\section{Tissue preparation}

One gramme of liver, kidney, brain and testis was homogenised in 2 $\mathrm{ml}$ of buffer solution of phosphate buffer saline $1: 2(\mathrm{w} / \mathrm{v} ; 1 \mathrm{~g}$ tissue with $2 \mathrm{ml} \mathrm{TBS}, \mathrm{pH} 7.4$ ). Homogenates were centrifuged at $10000 \mathrm{xg}$ for $15 \mathrm{~min}$ at $4{ }^{\circ} \mathrm{C}$ and the resultant supernatant was used for the determination of thiobarbituric acid reactive substances (TBARS), reduced glutathione (GSH) and protein levels in one hand and the estimation of GSH-Px activity in the other hand.

\section{Biochemical profile}

Different biochemical parameters were measured by spectrophotometric methods using the corresponding kits from Spin react (Spain, refs: glucose-1001190, triglycerides-41031, cholesterol1001090, urea-1001331, creatinine-, bilirubin-1001044, total protein-1001291, (ALP) alkaline phosphatase-1001130-1001131, (AST) aspartate aminotransferase-1001160-1001161 and (ALT) alanine aminotransferase-1001170-1001171).

\section{Determination of lipid peroxidation}

The lipid peroxidation levels in liver, kidney, brain and testis homogenates were measured as malondialdehyde (MDA) which is the end product of lipid peroxidation and reacts with thiobarbituric acid (TBA) as a TBARS to produce a red-colored complex with a peak absorbance at $532 \mathrm{~nm}$ according to Buege and Aust [21]. Thus, 125 $\mathrm{ml}$ of supernatant were homogenised by sonication with $50 \mathrm{ml}$ of PBS, $125 \mathrm{ml}$ of trichloroacetic acid-butylhydroxytoluene in order to precipitate proteins and then centrifuged $\left(1000 \mathrm{~g}, 10 \mathrm{~min}, 4^{\circ} \mathrm{C}\right)$. Then, $200 \mathrm{ml}$ of supernatant were mixed with $40 \mathrm{ml}$ of $\mathrm{HCl}(0.6 \mathrm{M})$ and $160 \mathrm{ml}$ of TBA dissolved in Tris and then the mixture was heated at $80{ }^{\circ} \mathrm{C}$ for $10 \mathrm{~min}$. The absorbance of the resultant supernatant was obtained at $530 \mathrm{~nm}$. The amount of MDA was calculated using a molar extinction coefficient of $1.56 \times 10^{5} \mathrm{M} / \mathrm{cm}$.

\section{Reduced glutathione (GSH) levels}

GSH level was estimated using a colorimetric technique, as mentioned by Jollow et al. [22]. This assay is based on the development of yellow colour when DTNB (5, 5' dithiobis-(2nitrobenzoic acid) is added to compounds containing sulfhydryl groups. In brief, $0.8 \mathrm{ml}$ of liver supernatant was added to $0.3 \mathrm{ml}$ of $0.25 \%$ sulfosalicylic acid and then tubes were centrifuged at $2500 \mathrm{x}$ $\mathrm{g}$ for $15 \mathrm{~min}$. Supernatant $(0.5 \mathrm{ml})$ was mixed with $0.025 \mathrm{ml}$ of 0.01 $\mathrm{M}$ DTNB and $1 \mathrm{ml}$ phosphate buffer $(0.1 \mathrm{M}, \mathrm{pH}$ 7.4). The absorbance at $412 \mathrm{~nm}$ was recorded. Finally, total GSH content was expressed as $\mathrm{nmol} \mathrm{GSH} / \mathrm{mg}$ protein.

\section{Glutathione peroxidase (GPx) activity}

Glutathione peroxidase (GPx) (E. C. 1.1.1.1.9) activity was measured by the procedure of Flohe and Gunzler [23]. Supernatant obtained after centrifuging $5 \%$ liver, kidney, brain and testis homogenate at $15000 \mathrm{xg}$ for $10 \mathrm{~min}$ followed by $10.000 \mathrm{xg}$ for $30 \mathrm{~min}$ at $4{ }^{\circ} \mathrm{C}$ was used for GPx assay. $1 \mathrm{ml}$ of the reaction mixture was prepared which contained $0.3 \mathrm{ml}$ of phosphate buffer (0.1 M, pH 7.4), $0.2 \mathrm{ml}$ of GSH $(2 \mathrm{mmol}), 0.1 \mathrm{ml}$ of sodium azide $(10 \mathrm{mmol}), 0.1 \mathrm{H}_{2} \mathrm{O}_{2}(1 \mathrm{mmol})$ and $0.3 \mathrm{ml}$ of liver supernatant. After incubation at $37^{\circ} \mathrm{C}$ for $15 \mathrm{~min}$, the reaction was terminated by addition of $0.5 \mathrm{ml} 5 \%$ TCA. Tubes were centrifuged at $1500 \mathrm{xg}$ for $5 \mathrm{~min}$, and the supernatant was collected. $0.2 \mathrm{ml}$ of phosphate buffer $(0.1 \mathrm{M}, \mathrm{pH} 7.4)$ and $0.7 \mathrm{ml}$ of DTNB $(0.4$ $\mathrm{mg} / \mathrm{ml}$ ) were added to $0.1 \mathrm{ml}$ of reaction supernatant. After mixing, absorbance was recorded at $420 \mathrm{~nm}$.

\section{Protein assay}

The protein content of tissues samples was measured by the method of Bradford [24], using bovine serum albumin as a standard.

\section{Statistical analysis}

Data were analysed using the statistical software MINITAB 16. Statistical analysis between all groups was performed with one-way 
ANOVA followed by Fisher's LSD (Least Significant Difference) test to evaluate the significance of differences. All experimental data were expressed as means \pm standard deviation (SD). Means that do not share a letter are significantly different.

\section{Results}

\section{Effects of treatments on body, absolute and relative weights}

Table 1 shows the body, absolute and relative organ weights (liver, kidney, brain and testis) of the control and experimental groups. The significant changes occurred in the experimental groups when compared with the control. The body weight has increased progressively throughout the study in all the groups associated with marked growth retardation of the rats treated by metribuzin although there were no significant differences between them. A significant increase of Mtz treated group in relative liver $(+25.33 \%)$, kidney $(+36.73 \%)$, brain $(+12.19 \%)$ and testis $(+9.43 \%)$ weights was also recorded when compared with their respective control rats. However, vanillin supplementation reserved these changes after $3 \mathrm{w}$ of treatment.

\section{Effects of treatments on plasma haematological parameters}

The results of a haematological profile in rats of control and treated group are presented in table 2 . Animals treated with metribuzin had significant lower RBC count $(-17.16 \%, \varangle 0.05), \mathrm{Hb} \quad(-20.38 \%$, $\mathrm{p} \leq 0.02)$ and HCT $(-23.92 \%, \mathrm{p} \leq 0.003)$ compared to the control group. The mean corpuscular volume (MCV), mean corpuscular haemoglobin (MCH) and mean corpuscular haemoglobin concentration (MCHC) were not statically significant than that of the control. Whereas, in rats co-treated with vanillin, there were no significant changes in haematological parameters when compared with the control values.

\section{Effects of treatments on plasma biochemical parameters}

Data represented in table 3 show that oral treatment with metribuzin caused significant decrease $(-9.03 \%, \mathrm{p} \leqslant 0.009)$ in total serum protein whilst a significant increase was noted in the level of glucose, urea, creatinine, bilirubin and cholesterol by $(6.76,43.34$, 73.47, 41.96 and 29.17\%; respectively) compared to the control $(\mathrm{p} \leq 0.0001)$. In addition, the activities of AST, ALT and ALP were significantly increased ( $\mathrm{p} \leq 0.006, \$ 0.001$ and $p \leq 0.0001)$ in metribuzin group compared to the control. In contrast, coadministration of vanillin to metribuzin treated animals restored most of these biochemical parameters to nearly normal levels.

\section{Effects of treatments on lipid peroxidation}

Results showed that metribuzin treatment caused significant increases of MDA levels (fig. 3, 4, 5 and 6) in all tissue tested, liver $(+19.31 \%$, $\ 0.0001)$, kidney $(+19.13 \%, \varangle 0.007)$, brain $(+20 \%$, $\mathrm{p} \leq 0.02)$ and testis $(+19.05 \%, \mathrm{p} \leq 0.003)$ when compared with their respective controls. Vanillin administered at $150 \mathrm{mg} / \mathrm{kg}$ to rats of $(\mathrm{Mtz}+\mathrm{Va})$ group alleviated lipid peroxidation and modulated significantly the levels of MDA in liver, kidney, brain and testis.

\section{Effects of treatments on reduced glutathione contents}

Data concerning liver, kidney, brain and testis reduced glutathione contents are presented in fig. 3, 4, 5 and 6. In Mtz group, statistically, significant differences were observed in liver $(-27.43, \mathrm{p} \leq 0.0001)$, kidney $(-17.7 \%, \mathrm{p} \leq 0.0001)$, brain $(-14.59 \%, \mathrm{p} \leq 0.03)$ and testis (22.97, $\ll 0.02$ ) compared to controls. Administration of vanillin improved liver, kidney, brain and testis reduced glutathione levels in $(\mathrm{Mtz}+\mathrm{Va})$ group compared to those of Mtz group.

\section{Effects of treatments on glutathione peroxidase activity}

Data of glutathione peroxidase activity measured in liver, kidney, brain and testis are presented in fig. 3, 4, 5 and 6. Administration of Mtz for 21 consecutive days induced significant decreases in GPX activity of liver $(-34.78 \%, \mathrm{p} \leq 0.0001)$, kidney $(-18.75 \%, \mathrm{p} \leq 0.005)$, brain $(-21.05, \mathrm{p} \leq 0.02)$ and testis $(-16.67 \%, \mathrm{p} \leq 0.001)$ compared to the controls. However, co-administration of vanillin with Mtz ameliorated GPx activity.

Table 1: Effect of metribuzin and its combination with vanillin on body weight, absolute and relative organ (liver, kidney, brain and testis) weights

\begin{tabular}{|c|c|c|c|c|}
\hline Parameters & Control & Va & Mtz & Mtz +Va \\
\hline Initial body weight (g) & $266.62 \pm 33.36$ & $267.75 \pm 31.67$ & $266.37 \pm 31.07$ & $270.88 \pm 25.56$ \\
\hline Final body weight (g) & $303.75 \pm 27.14^{\mathrm{a}}$ & $298.38 \pm 28.72^{\mathrm{a}}$ & $275.88 \pm 30.55^{a}$ & $293.63 \pm 29.07 \mathrm{a}$ \\
\hline Absolute liver weight (g) & $9.09 \pm 0.60^{\mathrm{bc}}$ & $8.57 \pm 1.02^{c}$ & $10.60 \pm 0.72^{\mathrm{a}}$ & $9.70 \pm 0.51^{b}$ \\
\hline Relative liver weight (g) (g/100 g b.w.) & $3.00 \pm 0.12^{c}$ & $2.87 \pm 0.14^{c}$ & $3.76 \pm 0.32^{\mathrm{a}}$ & $3.32 \pm 0.21^{\mathbf{b}}$ \\
\hline Absolute kidney weight (g) & $1.50 \pm 0.18^{c}$ & $1.52 \pm 0.07 \mathrm{bc}$ & $1.83 \pm 0.10^{\mathrm{a}}$ & $1.63 \pm 0.09 \mathrm{~b}$ \\
\hline Relative kidney weight (g/100 g b.w.) & $0.49 \pm 0.03^{c}$ & $0.51 \pm 0.03^{c}$ & $0.67 \pm 0.04^{\mathrm{a}}$ & $0.56 \pm 0.03^{b}$ \\
\hline Absolute brain weight (g) & $1.23 \pm 0.08^{\mathrm{a}}$ & $1.22 \pm 0.09 \mathrm{a}$ & $1.26 \pm 0.13^{\mathrm{a}}$ & $1.21 \pm 0.04^{\mathrm{a}}$ \\
\hline Relative brain weight (g/100 g b.w.) & $0.41 \pm 0.05^{b}$ & $0.41 \pm 0.02^{\mathbf{b}}$ & $0.46 \pm 0.08^{a}$ & $0.41 \pm 0.03^{\mathrm{ab}}$ \\
\hline Absolute testis weight (g) & $3.22 \pm 0.26^{\mathrm{a}}$ & $3.20 \pm 0.49^{a}$ & $3.28 \pm 0.36^{a}$ & $3.07 \pm 0.15^{\mathrm{a}}$ \\
\hline Relative testis weight (g/100 g b.w.) & $1.06 \pm 0.08^{b}$ & $1.07 \pm 0.09$ ab & $1.16 \pm 0.11^{\mathrm{a}}$ & $1.03 \pm 0.10^{\mathrm{b}}$ \\
\hline
\end{tabular}

Va: vanillin; Mtz: metribuzin, Values are mean \pm SD for groups of 8 animals each. ab-cMeans in a row without a common superscript letter are significantly different.

Table 2: Effect of metribuzin and its combination with vanillin on red blood cell (RBC), haemoglobin (Hb) concentration, haematocrit (HCT), mean corpuscular haemoglobin (MCH), mean corpuscular volume (MCV) and mean corpuscular haemoglobin concentration (MCHC)

\begin{tabular}{|c|c|c|c|c|}
\hline Parameters & Control & Va & Mtz & Mtz + Va \\
\hline $\mathrm{RBC}\left(\times 10^{6} / \mathrm{ul}\right)$ & $9.15 \pm 0.75^{a}$ & $9.25 \pm 1.13^{a}$ & $7.58 \pm 2.16^{b}$ & $9.13 \pm 0.75^{a}$ \\
\hline $\mathrm{Hb}(\mathrm{g} / \mathrm{dl})$ & $16.14 \pm 1.00^{a}$ & $15.86 \pm 1.65^{a}$ & $12.85 \pm 3.95 \mathrm{~b}$ & $15.48 \pm 0.98^{a}$ \\
\hline HCT (\%) & $45.77 \pm 3.42^{\mathrm{a}}$ & $44.14 \pm 3.94^{a}$ & $34.82 \pm 9.65^{b}$ & $42.91 \pm 3.20^{\mathrm{a}}$ \\
\hline $\operatorname{MCV}(\mathrm{fl})$ & $50.62 \pm 4.56^{\mathrm{a}}$ & $47.75 \pm 4.89^{a}$ & $46.5 \pm 1.93{ }^{a}$ & $48.25 \pm 6.18^{a}$ \\
\hline $\mathrm{MCH}(\mathrm{pg})$ & $17.81 \pm 1.11^{\mathrm{a}}$ & $17.20 \pm 0.95^{\mathrm{a}}$ & $16.85 \pm 0.96^{\mathrm{a}}$ & $17.38 \pm 1.30^{\mathrm{a}}$ \\
\hline $\operatorname{MCHC}(\mathrm{g} / \mathrm{dl})$ & $35.31 \pm 1.75^{a}$ & $35.96 \pm 2.55^{\mathrm{a}}$ & $36.2 \pm 2.60^{\mathrm{a}}$ & $35.66 \pm 2.71^{\mathrm{a}}$ \\
\hline
\end{tabular}

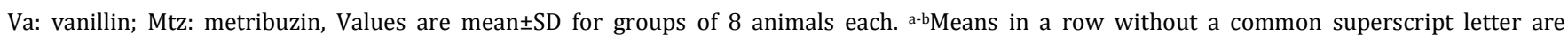
significantly different. Statistically significantly differences from all the groups: (RBC, $\mathrm{p} \leq 0.05)$; $(\mathrm{Hb}, \mathrm{p} \leq 0.02) ;(\mathrm{HCT}, \mathrm{p} \leq 0.003)$. 
(a)

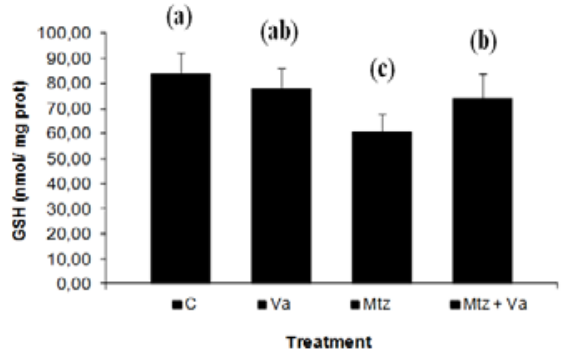

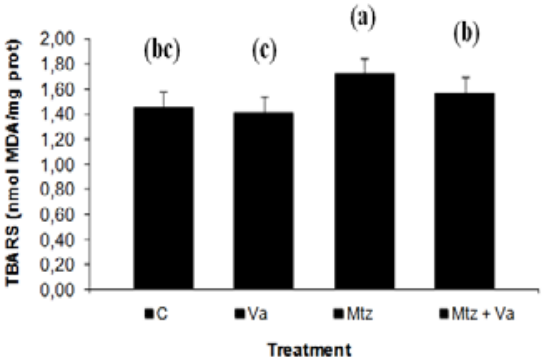

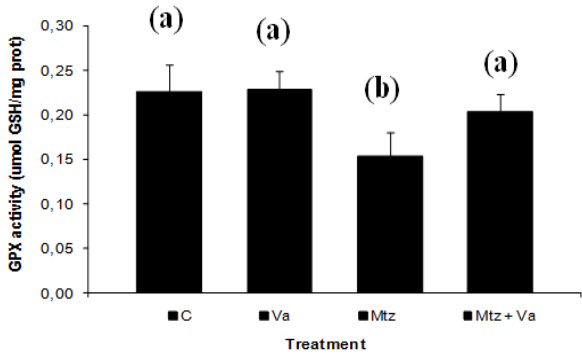

Fig. 3: Effect of metribuzin (Mtz) and its combination with vanillin (Va) on liver TBARS (nanomoles of MDA per milligramme of protein), reduced glutathione (nanomoles per milligramme of protein) and glutathione peroxidase activity. Values are given as mean \pm SD for groups of 8 animals each. ${ }^{a-b-c}$ Means that do not share the same letter are significantly different. Significantly differences from all the groups: (MDA, GSH and GPX; $p \leq$ 0.0001). TBARS: thiobarbituric acid reactive substances; MDA: malondialdehyde
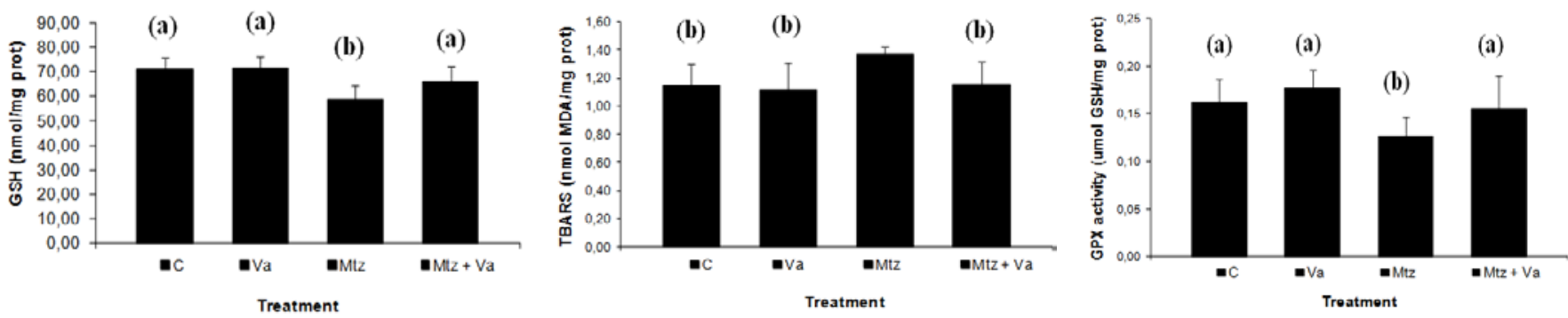

Fig. 4: Effect of metribuzin (Mtz) and its combination with vanillin (Va) on kidney TBARS (nanomoles of MDA per milligramme of protein), reduced glutathione (nanomoles per milligramme of protein) and glutathione peroxidase activity. Values are given as mean \pm SD for groups of 8 animals each. ${ }^{a-b}$ Means that do not share the same letter are significantly different. Significantly differences from all the groups: (MDA, $p$ 0.007): (GSH, $p \leq 0.0001$ ); (GPx, $p \leq 0.005$ ). TBARS: thiobarbituric acid reactive substances; MDA: malondialdehyde
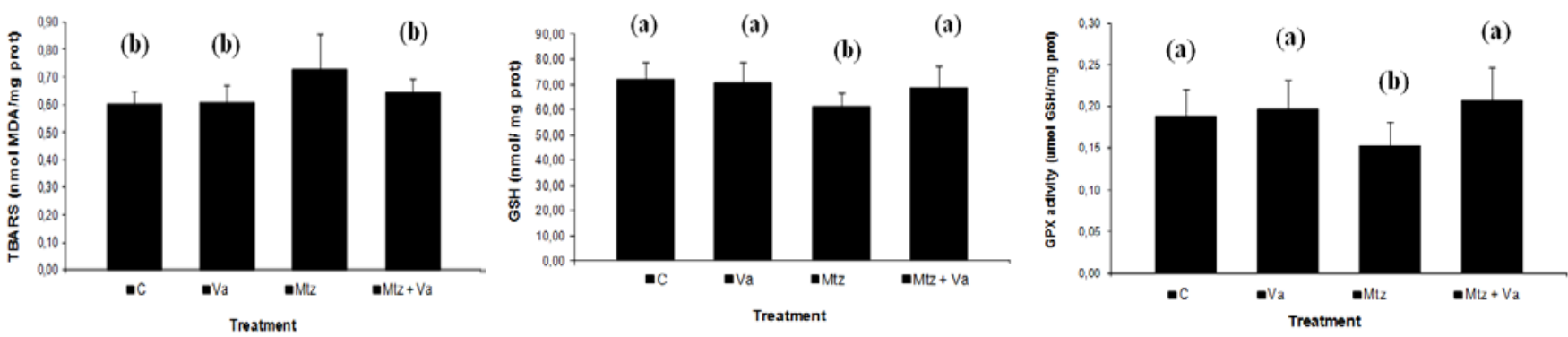

Fig. 5: Effect of metribuzin (Mtz) and its combination with vanillin (Va) on brain TBARS (nanomoles of MDA per milligramme of protein), reduced glutathione (nanomoles per milligramme of protein) and glutathione peroxidase activity. Values are given as mean \pm SD for groups of 8 animals each. ${ }^{a-b}$ Means that do not share the same letter are significantly different. Significantly differences from all the

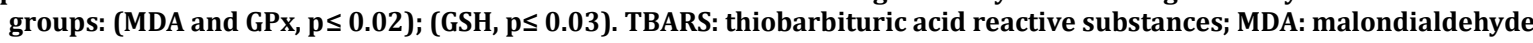
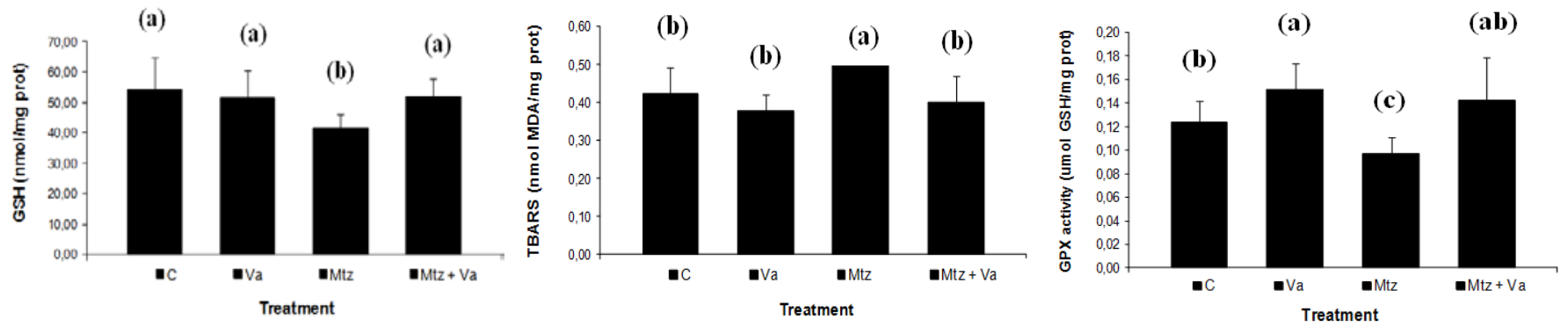

Fig. 6: Effect of metribuzin (Mtz) and its combination with vanillin (Va) on testis TBARS (nanomoles of MDA per milligram of protein), reduced glutathione (nanomoles per milligram of protein) and glutathione peroxidase activity. Values are given as mean $\pm S D$ for groups of 8 animals each. ${ }^{a-b-c}$ Means that do not share the same letter are significantly different. Significantly differences from all the groups: (MDA,

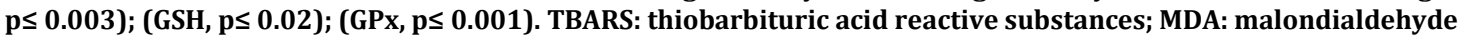


Table 3: Effect of metribuzin and its combination with vanillin on plasma glucose, total protein, bilirubin, blood urea, creatinine, aspartate aminotransferase (AST), alanine aminotransferase (ALT) and alkaline phosphatase (ALP)

\begin{tabular}{|c|c|c|c|c|}
\hline Parameters & Control & Va & Mtz & Mtz +Va \\
\hline Glucose (mg/dl) & $107.25 \pm 6.09 \mathrm{bc}$ & $104.63 \pm 4.14^{c}$ & $114.5 \pm 2.20^{\mathrm{a}}$ & $109.88 \pm 2.90^{b}$ \\
\hline Urea (mg/dl) & $39.5 \pm 6.70^{\mathrm{b}}$ & $37.63 \pm 4.24 \mathbf{b}$ & $56.62 \pm 7.59^{a}$ & $42.38 \pm 4.07 \mathbf{b}$ \\
\hline Creatinine (mg/dl) & $0.49 \pm 0.08^{b}$ & $0.44 \pm 0.12^{b}$ & $0.85 \pm 0.10^{\mathrm{a}}$ & $0.52 \pm 0.11^{b}$ \\
\hline Cholesterol (g/l) & $0.96 \pm 0.13^{b c}$ & $0.94 \pm 0.12^{c}$ & $1.24 \pm 0.18^{a}$ & $1.10 \pm 0.11^{b}$ \\
\hline Triglycerides (g/l) & $0.95 \pm 0.08^{b}$ & $0.91 \pm 0.13^{b}$ & $1.12 \pm 0.09^{a}$ & $0.98 \pm 0.13^{b}$ \\
\hline Total protein (g/l) & $71.75 \pm 4.12^{\mathrm{a}}$ & $72.23 \pm 3.36^{\mathrm{a}}$ & $65.27 \pm 5.41^{b}$ & $70.07 \pm 3.44^{\mathrm{a}}$ \\
\hline Total bilirubin (mg/l) & $5.10 \pm 0.60^{b}$ & $4.92 \pm 0.31^{b}$ & $7.24 \pm 0.91^{\mathrm{a}}$ & $5.43 \pm 0.79^{b}$ \\
\hline AST (U/l) & $79.62 \pm 5.83^{b}$ & $82.12 \pm 7.94^{b}$ & $90.87 \pm 4.85^{a}$ & $83.00 \pm 5.29 b$ \\
\hline $\operatorname{ALT}(\mathrm{U} / \mathrm{l})$ & $31.37 \pm 4.93^{c}$ & $34.62 \pm 4.66^{b c}$ & $44.12 \pm 7.64^{\mathrm{a}}$ & $38.00 \pm 4.75^{b}$ \\
\hline $\operatorname{ALP}(\mathrm{U} / \mathrm{l})$ & $145.12 \pm 9.33^{\mathbf{b}}$ & $146.75 \pm 11.11^{b}$ & $224.62 \pm 49.14^{\mathrm{a}}$ & $160.25 \pm 6.71^{b}$ \\
\hline
\end{tabular}

Va: vanillin; Mtz: metribuzin, Values are mean \pm SD for groups of 8 animals each. a-b-cMeans in a row without a common superscript letter are significantly different. Statistically significantly differences from all the groups: (glucose, urea, creatinine, cholesterol, bilirubin; $\mathrm{p} \leq 0.0001$ ); (total protein, $\mathrm{p} \leq 0.009)$; (triglycerides, $\mathrm{p} \leq 0.004)$; (AST, $\mathrm{p} \leq 0.006)$; (ALT, $\mathrm{p} \leq 0.001) ;($ ALP, $\mathrm{p} \leq 0.0001)$.

\section{DISCUSSION}

In the present study, the protective effect of vanillin against hematotoxicity, biochemical toxicity and oxidative damage induced by sub-acute exposure to metribuzin was undertaken.

After $21 \mathrm{~d}$, main hematological response of rats to the sub-acute exposure of metribuzin was a decrease of RBCs, Hb and HCT values compared to the control group. The decrease in $\mathrm{Hb}$ concentration and RBCs count observed in this study may be due to the effect of pesticides on erythropiotic tissue. The poisoning by pesticide residues causes anemia which come from reducing $\mathrm{Hb}$ biosynthesis and shortening the life span of circulating erythrocytes [25]. The reduced $\mathrm{Hb}$ synthesis may be responsible for decreased erythrocytic counts resulting in decline of heamtocrit values [26]. Similar changes in the haematocrit value, haemoglobin and erythrocyte counts were also reported by Velisek et al. [7] in fish following the acute poisoning with metribuzin.

Furthermore, treatment of rats with vanillin and metribuzin showed protective effects on haematological parameters. Corroborating with these results, the protective effects of other plant extracts against pesticide-induced hematotoxicity have been reported. For example, green tea protection against malathion-induced alteration of haematological parameters in rats was demonstrated in a study by Elzoghby et al. [9]. Dutta et al. [27] found that seed extract of Pterocarpus santalinus exerted beneficial effects.

Besides this, metribuzin exposure also brings some changes in the blood parameters. The results of our experimental study showed an increase in blood glucose levels after administration of metribuzin. The progressive accumulation of blood glucose revealed that rats exposed to Mtz became hyperglycemic which is in agreement with the findings of Chiali et al. [6] and Velisek et al. [7] who reported similar hyperglycemia in rat and fish treated with metribuzin. The rise in blood glucose produced by pesticides may indicate disrupted carbohydrate metabolism due to enhanced breakdown of liver glycogen, possibly mediated by increase in adrenocorticotrophic and glucagon hormones and/or reduced insulin activity [26].

While, vanillin supplementation effectively reduced the levels of blood glucose increased by Mtz exposure. As there are no scientific studies on its hypoglycemic activity, this case may be related to the biological effects of vanillin which are mainly attributed to the phenolic structure of such compound [18].

Plasma levels of urea and creatinine are important biomarkers of renal function in human and animal studies. An increase in the levels of these substances in the plasma is an indication of the loss of renal function [28]. Data from this study indicate that Mtz caused a significant increase in plasma urea and creatinine. This elevation may be due to kidneys damage caused by metribuzin. Also, Chiali et al. [6] reported that metribuzin can alter plasma urea and creatinine levels due to renal failure. Besides, similar observations have been reported in previous study following exposure to other pesticides $[29,30]$. Many pesticides can cause some toxic and adverse effects on the kidney tissues [9]. Therefore, the impairment in kidney function could probably occur via kidney oxidative damage [30].

However, in group treated by metribuzin plus vanillin there was a significant decrease of them when compared with metribuzin group. These results indicate that vanillin displays a remarkable protective effect on Mtz-induced renal damage which may be due to its antioxidant properties. So, a number of extracts of natural products and dietary antioxidants have been reported to show protective effects against nephrotoxicity. Overall, the findings suggest that the antioxidant properties of these compounds contribute significantly to its nephroprotective effect [31].

On the other hand, results from the serum lipid status of rats treated with Mtz showed significantly increased concentrations of serum cholesterol and triglyceride levels. Accordingly, El-Demerdasha and Nasr [32] also reported that pesticide increased plasma triglyceride levels which were attributed to an inhibition of the lipase activity of both the hepatic triglycerides and plasma lipoproteins. In addition, the increase in the level of serum cholesterol may be due to an increased cholesterol synthesis in the liver or it may be a sign of liver damage that can be attributed to the effect of pesticides on the permeability of liver cell membrane [32].

Interestingly, the observed results show that treatment of rats with vanillin caused apparent normalization in the total cholesterol and triglycerides levels. This is in accordance with the previous study where vanillin presented the reduction of cholesterol and triglyceride in the high-fat diet fed induced hyperlipidemic rats [33].

The activities of ALT, AST and ALP enzymes are the most sensitive biomarkers directly implicated in the extent of hepatic damage and toxicity [34]. In our findings, we demonstrated that Mtz administrated to rats provoked a marked elevation in serum AST, ALT and ALP activities which indicating hepatocellular damage as previously reported by Sief et al. [30] and Khalil et al. [35]. This elevation could potentially be attributed to the release of these enzymes from the cytoplasm into the blood circulation, indicating a necrosis and inflammatory reactions [34]. Regarding to total serum protein is the majority of serum proteins which are synthesized in the liver, so used as an indicator of liver impairment [9]. In the present work the rats administered metribuzin orally showed significant reduction in total protein which may be due to disturbance in protein synthesis in the liver due to hepatocytes dysfunction [9]. Also, the increase in serum total bilirubin of Mtztreated rats may result from decreased liver uptake, conjugation or increased bilirubin production from hemolysis [32].

Moreover, these adverse effects were significantly attenuated by vanillin in the treatment group which indicated a prominent hepatoprotective effect of Va against metribuzin toxicity. In another study, the hepatoprotective effects by vanillin against $\mathrm{CC} 1_{4}$-induced liver damage were examined in male wistar albino rats [14]. It has been indicated that vanilin had significant anti-hepatotoxic activity and reducing the elevated levels of serum enzymes such as AST and ALT. Also, Makeni et al. [14] suggest that the hepatoprotective 
mechanisms of vanillin could be attributed to the inhibition of inflammatory response in the liver.

Oxidative damage primarily occurs through production of reactive oxygen species including hydroxyl radicals and hydrogen peroxide that are generated during the reaction and react with biological molecules, eventually damaging membranes and other tissues [36] Lipid peroxidation is a chemical mechanism capable of disrupting the structure and the function of the biological membranes that occurs as a result of free radical attack on lipids which was usually reflected by levels of MDA [37]. Therefore, it has used as biomarkers of pesticides induced oxidative stress and suggested as one of the molecular mechanisms involved in pesticides-induced toxicity [38]. From the other side, GSH is an important naturally occurring antioxidant which prevents free radical damage and helps detoxification by conjugating with chemicals. Also, it is central to the cellular antioxidant defences and acts as an essential cofactor for antioxidant enzymes including GPx [39].

The results of the present study indicated that sub-acute exposure to metribuzin induced oxidative stress in all tissues tested, as evidenced by elevated MDA levels, reduced GSH contents and decreased GPx activities. All these findings lead to the conclusion that the oxidative stress due to metribuzin may be ascribed to the induction of ROS production as evidenced by increased LPO levels, resulting in the depletion of GSH contents that could be the cause of decreased activity of GPx. These results were in line with previous studies which have shown that exposure to pesticide generates lipid peroxidation and alters the antioxidant status of several tissues in rats [38, 40,41].

Moreover, a reduction in the oxidative damage was observed in metribuzin-vanillin group with elevation in the level of GSH and enzymatic antioxidant (GPx). This improvement may have resulted from vanillin provided a significant recovery in the level of ROS in metribuzin exposed animals in tissues. Indeed, vanillin presents different functional groups including the phenolic group. The antioxidant activity of phenols is attributed to their ability to scavenge free radicals [19]. So, like other polyphenols of its genre vanillin is a very potent free radical scavenger with ability for direct and specific scavenging of free radicals [42].

\section{CONCLUSION}

Our in vivo data shows that Va can be effectively used for application to overcome the oxidative damage induced by pesticide. Generally, vanillin presented ameliorative effect as rats receiving this phenolic in addition to metribuzin. Vanillin minimized the toxicity induced by metribuzin and its protective effect against oxidative damage could be explained by its antioxidant properties. Further studies on different animal and human models are essential to ensure the beneficial effects of vanillin. In addition, our findings show that Mtz may induce oxidative stress in some tissues and future histological studies are needed to confirm this finding.

\section{ACKNOWLEDGMENT}

The present research was supported by the Algerian Ministry of Higher Education and Scientific Research, Directorate General for Scientific Research and Technological Development through the Research Laboratory "Laboratory of Biochemical and Environmental Toxicology" Faculty of Sciences, University of Badji Mokhtar, Annaba, Algeria.

\section{CONFLICT OF INTERESTS}

\section{Declared none}

\section{REFERENCES}

1. Magnarelli G, Fonovich T. Protein phosphorylation pathways disruption by pesticides. ABC 2013;3:460-74.

2. Hernández AF, Lacasaña M, Gil F, Rodríguez-Barrancob M, Pla $A$, López-Guarnidoa 0 . Evaluation of pesticide-induced oxidative stress from a gene-environment interaction perspective. Toxicology 2013;307:95-102.

3. Maksymiv IV, Husak VV, Mosiichuk NM, Matviishyn TM, Sluchyk IY, Storey JM, et al. Hepatotoxicity of herbicide sencor in goldfish may result from induction of mild oxidative stress. Pestic Biochem Physiol 2015;122:67-75.
4. Medjdoub A, Merzouk SA, Merzouk H, Chiali FZ, Narce M. Effects of mancozeb and metribuzin on in vitro proliferative responses and oxidative stress of human and rat spleen lymphocytes stimulated by mitogens. Pestic Biochem Physiol 2011;101:27-33.

5. Koutnik D, Stara A, Velisek J. The effect of selected triazines on fish: a review. Slov Vet Res 2015;52:107-31.

6. Chiali FZ, Merzouk H, Merzouk SA, Medjdoub A, Narce M. Chronic low level metribuzin exposure induces metabolic alterations in rats. Pestic Biochem Physiol 2013;106:38-44.

7. Velisek J, Svobodova Z, Piackova V, Novotny L, Blahova J, Sudova E, et al. Effects of metribuzin on rainbow trout (Oncorhynchus mykiss). Vet Med 2008;53:324-32.

8. Al-Attar AM. Effect of grapeseed oil on diazinon-induced physiological and histopathological alterations in rats. Saudi J Biol Sci 2015;22:284-92.

9. Elzoghby RR, Hamuoda AF, Abdel-Fatah A, Farouk M. Protective role of vitamin $\mathrm{c}$ and green tea extract on malathioninduced hepatotoxicity and nephrotoxicity in rats. Am J Pharmacol Toxicol 2014;9:177-88.

10. Zaki NI. Evaluation of profenofos intoxication in white rats. Nat Sci 2012;10:67-77.

11. Ojo AO, Oyinloye BE, Ajiboye BO, Ojo AB, Akintayo CO, Okezie B. Dichlorvos induced nephrotoxicity in rat kidney: protective effects of Alstonia boonei stem bark extract. Indian J Pharmacol 2014;1:429-37.

12. Newairy AA, Abdou HM. Effect of propolis consumption on hepatotoxicity and brain damage in male rats exposed to chlorpyrifos. Afr J Biotechnol 2013;12:5232-43.

13. Suganya $\mathrm{P}$, Nandhini $\mathrm{R}$, Jeyadoss $\mathrm{T}$, Velavan $\mathrm{S}$. In vitro antioxidant activity of methanolic extract of Shorea robusta in hepatocytes. Int J Pharm Pharm Sci 2014;6:227-30.

14. Makni M, Chtourou Y, Fetoui H, Garoui EM, Boudawara T, Zeghal N. Evaluation of the antioxidant, anti-inflammatory and hepatoprotective properties of vanillin in carbon tetrachloridetreated rats. Eur J Pharmacol 2011;668:133-9.

15. Martins N, Barros L, Ferreira ICFR. In vivo antioxidant activity of phenolic compounds: facts and gaps. Trends Food Sci Technol 2016;48:1-12.

16. Raghavendra M, Madhusudhana Reddy A, Raghuveer Yadav $P$, Sudharshan Raju A, Siva Kumar L. Comparative studies on the in vitro antioxidant properties of methanolic leafy extracts from six edible leafy vegetables of India. Asian J Pharm Clin Res 2013;6:96-9.

17. Kim JH, Lee HO, Cho YJ, Kim J, Chun J, Choi J, et al. A vanillin derivative causes mitochondrial dysfunction and triggers oxidative stress in Cryptococcus neoformans. PLoS One 2014;9:e89122. http://dx.doi.org/10.1371/journal.pone.0089122.

18. Dhanalakshmi C, Manivasagam T, Nataraj J, Justin Thenmozhi A, Mohamed Essa M. Neurosupportive role of vanillin, a natural phenolic compound, on rotenone induced neurotoxicity in $\mathrm{SH}-$ SY5Y neuroblastoma cells. J Evidence-Based Complementary Altern Med 2015. Doi:10.1155/2015/626028

19. Oliveira CBS, Meurer YSR, Oliveira MG, Medeiros WMTQ, Silva FON, Brito ACF, et al. Comparative study on the antioxidant and anti-Toxoplasma activities of vanillin and its resorcinarene derivative. Molecules 2014;19:5898-912.

20. Xhaxhiu K, Shllaku J, Sula L, Xhelaj A, Kota T. The removal of metribuzin from pesticide contaminated waters using natural and activated prrenjasi-clay. Natura Montenegrina, Podgorica 2013;12:505-19.

21. Buege JA, Aust SD. Microsomal lipid peroxidation. Methods Enzymol 1984;105:302-10.

22. Jollow DJ, Mitchell JR, Zamppaglione Z, Gillette JR. Bromobenzene induced liver necrosis. Protective role of glutathione and evidence for 3,4-bromobenzene oxide as the hepatotoxic metabolites. Pharmacology 1974;11:51-17.

23. Flohe L, Gunzler WA. Analysis of glutathione peroxidase. Methods Enzymol 1984;105:114-21.

24. Bradford M. A rapid and sensitive method for the quantities of microgram quantities of protein utilizing the principle of protein binding. Anal Biochem 1976;72:248-54.

25. Yassa VF, Girgis SM, Abumourad IMK. Potential protective effects of vitamin $\mathrm{E}$ on diazinon-induced DNA damage and 
some haematological and biochemical alterations in rats. J Mediterranean Ecol 2011;11:31-9.

26. Mehra BL, Sharma P, Kaushik U, Joshi SC. Effect of fytolan on haematology and serum parameters of male albino rats. Int J Pharma Res Health Sci 2014;2:332-8.

27. Dutta K, Ali M, Najam A, Kumar R, Kumar A. Ameliorative effect of seed extract of Pterocarpus santalinus on coragen induced haematological alterations and serum biochemical changes in charles foster rats. J Toxicol Environ Health Sci 2014;6:194-202.

28. Olayinka ET, Ore A. Hepatotoxicity, nephrotoxicity and oxidative stress in rat testis following exposure to haloxyfop-p-methyl ester, an aryloxyphenoxypropionate herbicide. Toxics 2015;3:373-89.

29. Nazam N, Iqbal Lone M, Sharma M, Khan AA, Kelany AM, Ahmad W. Biochemical and cytoarchitechtural evaluation of dimethoate intoxication in rat liver and kidney: an in vivo study. Indo Am J Pharm Res 2015;5:1127-37.

30. Sief MM, Khalil FA, Abou Arab AAK, Abou Donia MA, ElSherbiny AM, Mohamed SR. Ameliorative role of Melissa officinalis against hepatorenal toxicities of organophosphorus malathion in male rats. MOJ Toxicol 2015;1:00014. Doi:10.15406/mojt.2015.02.00014

31. Rajagopal PL, Premaletha K, Kiron SS, Sreejith KR. A review on nephroprotective herbs and herbal formulations. Int J Pharm Chem Sci 2013;2:1888-1904.

32. El-Demerdash FM, Nasr HM. Antioxidant effect of selenium on lipid peroxidation, hyperlipidemia and biochemical parameters in rats exposed to diazinon. J Trace Elem Med Biol 2014;28:89-93.

33. Belagali Y, Ullal SD, Shoeb A, Bhagwath V, Ramya K, Maskeri R. Effect of vanillin on lipid profile in a model of hyperlipidemia, a preliminary study. Indian J Exp Biol 2013;51:288-91.

34. Sidhu IPS, Bhatti JS, Bhatti GK. Modulatory action of melatonin against chlorpyrifos induced hepatotoxicity in Wistar rats. Asian J Med Sci 2014;2:123-31.

35. Khalil SM, Taha KM, Farid HES, Atia AF. Antioxidant role of olive "Olea europeavar picual" leaves extract on profenofos induced oxidative stress in male rats. Int J Adv Res 2014;2:635-50.
36. Heikal TM, Mossa ATH, Ibrahim AW, Abdel-Hamid HF. Oxidative damage and reproductive toxicity associated with cyromazine and chlorpyrifos in male rats: the protective effects of green tea. Res J Environ Toxicol 2014;8:53-67.

37. Osama A, Fatma A, Mohamed EB, Huda S. Studies on the protective effects of ginger extract and in combination with ascorbic acid against aluminum toxicity induced hematological disorders, oxidative stress and hepatorenal damage in rats. AVAS 2014;15:137-50.

38. Mossa ATH, Swelam ES, Mohafrash SMM. Sub-chronic exposure to fipronil induced oxidative stress, biochemical and histopathological changes in the liver and kidney of male albino rats. Toxicol Reports 2015;2:775-84.

39. Sultana M, Prawez S, Ahmad Dar M, Ahmad M, Naseem S. Sub acute dermal toxicity of metalaxyl with special reference to oxidative stress in Wistar rats. Asian J Sci Technol 2015;6:1316-8.

40. El-Kholy WM, Hemieda FAE, El-Zarif NA. Protective effect of aqueous extract of Anacyclus pyrethrum root on atrazineinduced male reproductive disorders in rats. Int J Adv Res 2015;3:1701-15.

41. Ojo OA, Oyinloye BE, Ajiboye BO, Ojo AB, Musa H, Olarewaju OI. Dichlorvos-induced oxidative stress in rat brain: Protective effects of the ethanolic extract of Alstonia boonei stem bark. Asian J Pharm 2014;8:216-21.

42. Al Asmari A, Al Shahrani H, Al Masri N, Al Faraidi A, Elfaki I, Arshaduddin M. Vanillin abrogates ethanol induced gastric injury in rats viamodulation of gastric secretion, oxidative stress and inflammation. Toxicol Reports 2016;3:105-13.

\section{How to cite this article}

- Lilia Kadeche, Ezzeddine Bourogaa, Mongi Saoudi, Ame Boumendjel, Assia Djeffal, Abdelfattah El Feki, Mahfoud Messarah. Ameliorative effects of vanillin against metribuzin-induced oxidative stress and toxicity IN rats. Int J Pharm Pharm Sci 2017;9(1):56-62. 